\title{
IN PASSING: ARAB AMERICAN POETRY AND THE POLITICS OF RACE
}

\author{
Katherine Wardi-Zonna \\ Gannon University \\ Anissa Janine Wardi \\ Chatham College
}

\section{THE POLITICS OF PASSING, OR BEARING WITNESS THROUGH THE BODY Incident \#1:}

Gulf War 1991-I am an undergraduate college student working part-time in an academic department. A male professor, whose wife is pregnant, is taken with my name, playfully singing its syllables and thrilled to tell me that his wife, too, agrees that they will name their baby girl Anissa. We banter about the uniqueness of my name and why it is just right for his daughter. Weeks later he asks in passing: "My wife and I assume that your parents just made up your name, right?" "No," I respond, without hesitation, "it's an Arabic name." He stammers, his face reddens, and he stutters, "What? But you're not; you couldn't be." "Yes," I say, "I am. My father was Iraqi." He avoids me for the rest of the semester. We never talk of my name or of his baby girl again. I learn later that they name her Emily. 


\section{Incident \#2:}

Gulf War 2003-I am a professor at a Catholic university who must somehow face my students and colleagues the day after President Bush wages what I perceive to be an unjust and immoral war against Iraq. I am speaking to a graduate student who recently converted to Islam. She covers, and is therefore marked as "other" in the West. A faculty member rapidly approaches us only to turn to the student with concerns: "I thought about you all last night through the bombing. Do you have family there? Is everybody okay?" The student explains that her family is not Arab; they are living in America and many of them are supporting the President's decision. As an American of Iraqi decent, I stand motionless: alone, erased, silenced and passing.

Racial passing has a long history in America. In fact, there are manifold reasons for passing, not the least of which is to reap benefits-social, economic and legal-routinely denied to people of color. Passing is conventionally understood to be a volitional act that either situationally or permanently allows members of marginalized groups to assimilate into a privileged culture. While it could be argued that those who choose to pass are, in a sense, race traitors, betraying familial, historical and cultural ties to personhood, ${ }^{1}$ Wald provides another way of reading passing, or "crossing the line," as a "practice that emerges from subjects' desires to control the terms of their racial definition, rather than be subject to the definitions of white supremacy" (6). She further contends that racial distinction, itself, "is a basis of racial oppression and exploitation" (6).

Underlying Wald's argument is the slipperiness, unreliability and instability of race as a category of identity, arbitrarily assigned to the physiognomy of bodies that conform to racial taxonomy. ${ }^{2}$ While W.E.B. Du Bois' prescient prediction that the problem of the 20th century is that of the "color line" is irrefutable and has, in fact, extended to the 21 st century, the basis for this discrimination is the existence of the social category of race and not some transcendent notion that race is a biological given. Numerous scholars have undermined essentialist notions of race; however, as Browder argues, "Race may be a construction, but color remains a visual cue; and most Americans use visual, physiological cues to make 
their judgments about a person's racial identity. The constructions of racial and ethnic identities have the psychological weight of reality" (9). While it is not our intention in this essay to reify race as an essential category of selfhood, we do contend that racial distinction continues to signify in direct and often totalizing ways, and thus Arab Americans' fraught history of racial classification underlies the politics of their current negotiation of racial registries in America.

Arabs have been classified within the racial rubrics of the United States government as "white" since 1978, despite, as Majaj cogently argues, being "popularly perceived as non-white" ("ArabAmericans and the Meanings of Race" 320). ${ }^{3}$ It should be noted that Arabs have not always been categorized as "white" in America. An examination of immigration laws and the experiences of Arab settlers illustrates the instability of the Arab population's racial position, one that Samhan concludes is best understood as "not quite white" (209). This is echoed by Joseph, in "Against the Grain of the Nation-The Arab," who argues, "[t]o be white has been understood historically to mean being of European extraction. ... Arabs are represented in the media as not quite white and not quite colored" (259). The current white status bestowed on Arabs, while legal, is, for many, considered "honorary." In the 19th century, Arabs were classified as originating from "Turkey in Asia," and later Arabic speaking immigrants were classified en masse as being "Syrians" who were often designated as Asian. ${ }^{4}$ In fact, Arabs began petitioning the courts to be considered "Caucasian" and not "Asiatic," presenting "historical and genealogical evidence of the Syrians' Caucasian origins" (Samhan 216).

Arabs from the late nineteenth century to the mid-twentieth century were caught in a liminal racial position, many considered non-white and others deemed "white" solely based on the color of their skin and not on a national policy: "judges were more likely to deem lighter-skinned applicants worthy of naturalization, and to deny naturalization to darker-skinned immigrants even when attributing rejection to other reasons. For instance, applicant Faras Shahid, described by the court as 'walnut or somewhat darker than is the usual mulatto,' and applicant George Dow, described as 'darker than the usual person of white European descent' were 
both initially excluded from naturalization, while applicant Tom Ellis, described as Semitic but 'a markedly white type of the race,' was admitted" (Majaj, "Arab-Americans and the Meanings of Race" 322).

This reliance on racial physiognomy was articulated by a South Carolina judge in 1914, who ruled in the context of a citizenship hearing, that "although Syrians might be free white persons, they were not 'that particular free white person to whom act of Congress [1790] had donated the privilege of citizenship,' a privilege he ruled was intended for persons of European descent" (Samhan 217). This position is by no means unique; there were numerous court cases in the early and middle twentieth century in which judges alternately and arbitrarily defined Arabs as white and non-white: "At stake in the cases were these questions: whether Arabs are "white" in color; whether Arabs are Asian or Caucasian; whether whiteness is determined by race, color, geography, culture or religion; and whether there is an intrinsic connection between Caucasian identity and whiteness" (Majaj, "Arab Americans and the Meanings of Race" 322). Here, it is clear that Arabs' white status was first and foremost contingent on racial physiognomy. Indeed, the South Carolina judge mentioned above reasoned that "[i]f an applicant from Syria cannot rest on complexion, he must find other grounds ... to establish any community of race with the European races assuming those last to be the white race" (Majaj, "Arab Americans and the Meanings of Race" 322).

While by no means an exhaustive history of Arab racial classification in America, these cases are presented to underscore the problematized racial identity of Arabs in America, a tension that is acutely significant and trenchant in today's climate. Beset with wars, questionable foreign policy decisions and acts of terror committed on both sides of the ocean, Arab Americans' simultaneous identification as American and not American, white and not quite white, confounds group identification with other communities of color and complicates the dynamics of passing for this population. ${ }^{5}$

Joanna Kadi, editor of Food for Our Grandmothers: Writings by Arab-American and Arab-Canadian Feminists, argues the following about the position of Arabs in the West: "Not Black. Not White. 
Never quite fitting in. Always on the edge" (xvi). Because Arabs occupy an in-between space of racial identification, Kadi contends, "In the United States and Canada, it is not only white people who refuse to see us, it is other people of color-Latinos, Africans, Asians, Natives-who do not acknowledge our existence" (xix$\mathbf{x x}$ ). African American poet June Jordan provides an important exception to Kadi's feelings of exclusion in communities of color. Jordan, who visited Lebanon in 1996, offers the following: "I went to Lebanon because I believe that Arab peoples and Arab Americans occupy the lowest, the most reviled spot in the racist mind of America. I went because I believe that to be Muslim and to be Arab is to be a people subject to the most uninhibited, lethal bullying possible" (qtd. in Saliba 304). Reviewing the video of the Israeli bombings at Qana, Jordan offers a striking analogy to African American experiences, claiming that it is the "Rodney King video of the Middle East" (qtd. in Saliba 304). In this way, Boudakian's "Crossing Over to the Other Side" printed in Kadi's anthology, reveals a homecoming in choosing to identify with women of color from whom she received "unequivocal support" (36) for what she regards as her process of mental decolonization: "Cultural bleach is a force in white supremacist U.S. mainstream culture, wherein light-skinned people of color are urged to consider ourselves physically, historically and ideologically white. Resisting cultural bleach is a refusal to participate in this kind of assimilation and instead to affirm who we are" (35). While Boudakian does not share Kadi's sentiment of liminality, in both positions selffashioning is a complicated process, fraught with historical, cultural and racial markers. Arab American writers, while exploring these identity issues, bear witness to their histories and political struggles regardless of how they situate themselves racially in America.

As the epigraphs reveal, passing is not only confined to chosen acts of racial disguise, but is often projected onto bodies that do not adhere to protocols of racial or ethnic classifications. Given the instability of racial categorization and the prevailing stereotypical assumptions about Arabs, many Arab Americans unintentionally pass for non-Arab in America. ${ }^{6}$ Mohja Kahf's "Hijab Scene \#5" explores the manifold issues surrounding unintentional passing and the problems of Arab racial classification. The speaker enjoys 
community with African American men only when covered: "When you're wearing hijab, Black men / you don't even know materialize / all over Hub City / like an army of chivalry, / opening doors, springing / into gallantry." Here, Islam is implicitly conflated with communities of color, for when the speaker marks herself as a Muslim she is regarded as an ally, acknowledged as a sister. However, the speaker's affiliation with the African American community is transient: "Drop the scarf, and (if you're light) / you suddenly pass (lonely) for white." These final two lines reveal how the Arab body may not disclose racial identity; rather, such identity may be manifest through external markers. Despite a lighter skin tone, the speaker positions herself as a person of color, who merely "passes" for white. That the word "lonely" is placed in a parenthetical allows for a dual reading, as the speaker not only passes for white, but her default position as white leaves her bereft of community, excluded from the majority culture and from communities of color. This poem articulates that, more often than not, members of the Arab American community are faced at some point with inadvertent passing.

African American performance artist Adrian Piper, whose physical features do not disclose her race, has adopted a unique approach to handling her own inadvertent passing by distributing cards that read: "I am black. I am sure that you did not realize this when you made/laughed at/agreed with that racist remark." The card continues by explaining that Piper tried early on to alert white people to her racial allegiance, which often resulted in people regarding her as "'pushy, manipulative, or socially inappropriate" (qtd. in Wald 4). This act of public performance reveals the nexus of concerns associated with racial identification: it is arbitrarily assigned by governmental agencies; it is a foundation of overt and implicit social interaction and it is a burden or responsibility. While not intending to pass as such, Piper's routine social interactions reveal that she does pass for white and is subject to racist remarks. It is here that race moves from a biological to a social category. Regardless of bloodlines, family or heritage, it is in these moments that Piper chooses to identify herself politically as an African American.

Likewise, Arabs, who often unwittingly pass, routinely consider 
the politics of whether or when to "out" themselves, perhaps not as "white" (which, again, theyarelegally defined), but as Arabs, a loaded signifier in this particular historical moment. The representation of Arabs as "essentially different and not comprehensible to the Western mind" (Joseph 258) is widespread and has a long history in America. Throughout the nineteenth century, the Arab was considered incapable of becoming Americanized. In 1899, a Boston social worker described Arabs as inherently "other": "Next to the Chinese. . . who can never be in any real sense Americans, the Syrians are the most foreign of all our foreigners. Whether on the street in their Oriental costumes, or in their rooms gathered around the Turkish pipe, they are always apart from us'" (Shakir 43).

Since the late 1960s, specifically following the 1967 Arab-Israeli War, the profoundly exotic image of the Arab has transformed into a far more sinister portrayal. The popular stereotype of the Arab is of a villain, who is encoded as male. The Arab male, so readily apparent as the embodiment of evil (or as the axis of evil, as it were), functions to tell us who "we" are: the "we are good" and "they are evil" dualism has currency in today's culture. In a study of comic books featuring Arabs from the 1980s, in which "not a single Arab heroine or hero was featured," Shaheen contends that the caricatures of Arab men fall essentially into three categories: "repulsive terrorist, the sinister sheikh or the rapacious bandit" who are "bestial, demonized and dehumanized" (123). Arab men are cast routinely as "anti-American, anti-West, anti-Israel, antiJewish, anti-Christian" (123). Arab women, depicted as "shadowy nonentities, swathed in black from head to foot" (Shakir 39), serve to reinforce Arab male brutality. Shaheen finds that the portrayal of the Arab woman is of a "faceless housewife, whose thick-set form is bundled in dark robes" and who is "voiceless, featureless and mindless" (129). ${ }^{\prime}$

Throughout the media, Arabs are now narrowly scripted as terrorists, madmen or religious fanatics, this latter term functioning as a euphemism for Islamic fanaticism:

Some political analysts have argued that Islam is the West's new evil empire. Islam is frequently represented as a militaristic religion bent on jihad 
(holy war), inherently and historically hostile to the democratic, Christian West. Islam's tenets often are represented as inscrutable. Adherents of Islam are frequently viewed as mindless, fanatic followers of mad clerics." (Joseph 261).

Despite the fact that the majority of Arabs in America are Christian, there is a conflation of Arabs with Islam, which Joseph considers "a religion of color." The stereotypes of Islam, then, are embedded in the West's cultural perception of Arab society $(259,260)$. These representations work to underscore the notion of the Arab/Muslim "other," who is, above all else, fundamentally not American. Because Arab Americans are a rather invisible minority, ${ }^{8}$ who do not have the political power that other groups in America enjoy, many Americans do not know Arabs or Muslims in their daily lives. Therefore, this "other" is understood through cultural representations, which rely today, as they did during the 19th century, on what Edward Said argues is an Orientalist gaze. He holds that "one of the principal dogmas of Orientalism is the absolute and systematic difference between the West, which is rational, developed, humane, superior, and the Orient or the East, which is aberrant, underdeveloped and inferior" (300). He further argues that, "without examining Orientalism as a discourse, one cannot possibly understand the enormously systematic discipline by which European culture was able to manage-and even produce-the Orient" (3). The concept of the "orient" was based on perceptions of racial otherness and difference. The insistence on creating and upholding negative stereotypes worked to justify wars, colonial expansion, and the exploitation of native peoples and resources. Orientalism continues today. Given this colonial history, and the fact that Arab Americans have been a silenced and invisible minority in America, it is perhaps easier for monolithic characterizations to circulate without a great deal of reaction or protest. Recognizing their status as "terrorists" and the feared embodiment of otherness-in short, recognizing that they are "the enemy" in this time of war-there are numerous reactions to inadvertent passing, but the shared responsibility for not bearing witness to family and heritage can result in feelings of guilt. 
Naomi Shihab Nye, arguably one of the best-known Arab American poets, writes poignantly of an incident of inadvertent passing in a theater in England. During intermission, a woman sitting next to Nye, without provocation, confided to the Palestinian American poet "You know what's wrong with the world today? It's Arabs. I blame it all on the Arabs. Most world problems can really be traced to them"" ("Long Overdue" 128). A stunned Nye is silenced, questioning the randomness of the older woman's vitriol. Though Nye had time to respond to the woman-"to find a vocabulary for prejudice and fear"-she remains immobilized: "I could have said, 'Madam, I am half Arab. I pray your heart grows larger someday.' I could have sent her off, stunned and embarrassed, into the dark" ("Long Overdue" 129). Replaying and textualizing this racist encounter and highlighting her silence, Nye discloses the guilt she feels for passing: "Oh I was ashamed for my silence and I have carried that shame across oceans, through a summer when it never rained, in my secret pocket, till now. I will never feel better about it" ("Long Overdue" 129). This episode from Nye's life suggests the dual roles that voice and body play in the contestation of white supremacy. ${ }^{9}$ When the body fails to signify, when the body "passes," voice can mitigate corporeal silence.

\section{BEARING WITNESS THROUGH THE WORD}

While Arab Americans have had a long history of publishing in America, Arab American writers from the latter half of the twentieth century in contrast to earlier Arab American writers punctuate their writing with issues of passing, racial identity, voice and political affiliation. These second and third generation writers, according to Majaj are "embedded in the affirmation of ethnicity popularized in the 1960s and 1970s" ("Arab American Literature and the Politics of Memory" 267).

It should be noted that "[w]ithin the Arab- American literary scene, there is much more poetry than fiction" (Akash and Mattawa xiii), and numerous reasons are hypothesized for writers' penchant for this genre, not the least of which is the relationship of Arab American writers to the Middle East. In the Arab world, oral performance of poetry is prized. The Koran exemplifies this 
poetic tendency for while it is first and foremost the spiritual book of Muslims, it is simultaneously a text of striking verse, made more lovely by its oral recitation. Orfalea and Elmusa find that Arab American poets are responding to their forebears' connection to this verbal art form: "The great Arab love of poetry [has] not been drained from New World veins" (xii). They continue by stressing that Arabs' "love of poetry is native and deep" (xiii). Others argue that poetry is favored because it is a genre suited to both grief and celebration. Given the demonized position of Arabs in America, coupled with the pain and suffering of so many Arabs in the Middle East, it is fitting that poetry functions as a site of mourning and remembrance. The elegiac tone of their writing situates Arab American writers within a larger framework of stereotyped groups in America whose literary expression seeks, in part, to call attention to a history of oppression and a legacy of neo-colonization. Echoing in the poetry of Nye is pain and loss on a domestic, national and international scale. Indeed, the ease with which the Arab American poet moves from depictions of familial household rituals to American foreign policy underscores that poetry, unlike the body, can consistently bear witness to Arab American lived experiences, which, while certainly not monolithic, pose a radical alternative to routine images in the West.

Nye's introduction to her poetry collection, 19 Varieties of Gazelle, works to apprehend the tragedy of September 11, 2001 by turning to poetry: "Writers, believers in words, could not give up words when the going got rough. I found myself, as millions did, turning to poetry. But many of us have always turned to poetry. Why should it be any surprise that people find solace in the most intimate literary genre? Poetry slows us down, cherishes small details. A large disaster erases those details. We need poetry for nourishment and for noticing, for the way language and imagery reach comfortably into experience, holding and connecting it more successfully than any news channel we could name" (xvi). Beginning her poetry collection with sorrow-a sorrow that millions of Americans, Arabs and Arab Americans share-reveals the shroud of loss permeating the collection. Through this opening, Nye announces her book as a text of memory that works to coalesce the community and give expression to its members' lives in the 
face of tragedy. When Nye learns of the devastation of $9 / 11$, she remembers the generosity and kindness of Arab men, including a "gentle Egyptian basket-seller" and an "elegant Arab man" who gave her twice the cloth she had paid for. She remembers Waleed, the restaurant owner, who cooked lentil soup for free for her son. It is these men, these quiet, gentle, generous men, who are effectively erased and silenced in the wake of such devastation, that Nye insists on naming, while never losing sight of the tragedy, a tragedy that she believes "Arab Americans must say, twice as clearly as anyone else, that we deplore" (xvi).

It is in these moments when Arab American writers proclaim "this is not who we are" (xviii) that our grief works to galvanize the community by rhetorically marking and quietly commemorating the lives of so many others: "the innocent citizens in the Middle East who haven't committed any crime" and "who are living solid, considerate lives, often in difficult conditions" (xvii). In this way, memory is a powerful counternarrative, a political text that allows for a new paradigm of the Arab world. Narrating the lives of Arab men who routinely and effortlessly demonstrate acts of kindness and generosity, Nye offers another text of Arab masculinity that is antithetical to terrorism, violence and hatred. ${ }^{10}$ Nye's father, her Palestinian father, is representative of her fusion of domestic and international politics. Throughout the collection, Nye's father is presented as a figure of domesticity who tells stories to the neighborhood children, is slow to anger, serves tea with sprigs of mint, sings folksongs, plants fig trees in the middle of Dallas, Texas, leans over the stove to boil Arabic coffee and dreams of his childhood in the Old City of Jerusalem.

Nye's grandmother, who lived to be 106, is a recurring figure in her poetry, but Arab men, emblematized by her father, are a touchstone of her work. So while Zoghby's argument that Arab American poets return to the family and especially parents as poetic subject matter provides a useful paradigm for reading Nye's work (22), her recurring reference to the father is perhaps more nuanced, for it is through the father's body that Nye is Arab. ${ }^{11}$ It is noteworthy that Nye, in recounting the racist incident in the theater, thinks of her father, wondering, "what would he say back to her?" ("Long Overdue" 129). Nye recalls her father at this 
moment partly because her shame at not speaking and confronting this woman could be understood as a betrayal of her father, a Palestinian who seemingly would not have the same facility at passing that his daughter does. Inadvertent passing, then, carries with it the recognition that others cannot pass and the attendant feelings of guilt for temporarily abdicating ethnicity.

Pairing the father's voice with her silence points toward the tension around language in many of Nye's poems. As a poet, language is her medium, yet it is often the inability to find speecha weighty silence, a wordlessness-that marks Nye's Arab poems. Arabic is defined as the language of pain and suffering in the poem "Arabic." As the man with the "laughing eyes" tells Nye, "Until you speak Arabic, / you will not understand pain"' (19 Varieties, 90) Nye, though, does not have full access to her father language: "I admit my / shame. To live on the brink of Arabic, tugging / its rich threads without understanding / how to weave its rug. . I I have no gift" (91). Because she believes her "gift" of language is stunted by her inability to speak Arabic fluently, she cannot speak its pain, cannot be its witness. However, by the poem's end, the speaker admits to "feeling sad" and responds to the man, "I'll work on it" (91). Nye's desire to "work on" expressing the pain of her people, to find a language that articulates their suffering, remains a site of longing in her work. This is exemplified in "The Man Who Makes Brooms," as the speaker is haunted by voices, pleading, "'speak for my people'" (19 Varieties, 18)..$^{12}$ Ironically, in this poem featuring the quiet gestures of the broom maker-"thumb over thumb, straw over straw"-Nye is speaking for her people. Occupying his small space, where there is "barely room / for baskets and threads," the broom maker remains. In this subtle treatment of place and ritual, Nye highlights the constancy and dignity of the man's work as a stance against Palestinian displacement. ${ }^{13}$ His work is holy simply because it continues. Significantly, the broom maker does not speak; rather, it is his gesture, to which Nye gives language, that invokes pain and loss. Nye understands the man's gentleness not by word, but by action. While she is outside of the broom maker's language, Nye can nonetheless speak his story. In fact, her marginalized status in America and the Middle East provides her with a lens with which read the universality of suffering. 
The final image of "Arabic" is of the speaker hailing "a taxi by shouting "Pain!" Although the poem withholds the language the speaker uses to hail the cab, it is significant that "the taxi stopped / in every language and opened its doors" (91). Nye's travel from America to Palestine, suggested by the movement of the taxi, indicates the transportation of pain. That all languages equally call the taxi, all nations sharing pain, is a metaphor for Nye's work. "All Things Not Considered" emblematizes this interconnection. In this poem, Nye chronicles the suffering in Palestine, where both Palestinian and Jewish people are murdered in the name of "holy land." Here, where "everyone hurts in similar ways," the speaker asks, "In what language / is this holy?" (19 Varieties, 133). Nye suggests that adhering to a particular language, an ideology, detracts from the ability to appreciate the collective language of humanity. Despite her intimate connection to the Arab world and her insight into its people's ongoing oppression, Nye's poetry arcs towards a larger conceptualization of reconciliation and compassion.

The recurrence of humane Arab men in Nye's writing does not work to romanticize nostalgic visions of a patriarchal Arab past, which, as Majaj rightly argues, can be a problem in Arab American literature, in which some authors conflate the beautiful land of the Middle East with women and those who tame it and preside over it as male ("Arab American Literature and the Politics of Memory" 275). Rather, given the decidedly gendered discourse in the West around the Arab "enemy," it is "he" who Nye seeks to confront textually. This is a political act of textual resurrection, and not a wistful turn for Nye, who is herself American and therefore is not longing for an Arab homeland in the same way as first generation Arab American authors might. Bearing witness to her ethnicity in her poetry and prose necessarily encompasses bearing witness to her father and other Arab men: "There is no one like him and there are thousands like him-gentle Arab daddies who make everyone laugh around the dinner table, who have a hard time with headlines, who stand outside in the evenings with their hands in their pockets staring toward the far horizon" ("Letter").

Nye's poetry does not decorate acts of violence, whether committed by fundamentalists or those working under the 
auspices of the Israeli government and with financial support from the United States. ${ }^{14}$ Nye does not anesthetize the pain of living in refugee camps where children are gunned down and mothers are left to mourn for the missing. In this way, the back cover of 19 Varieties of Gazelle, features an older Arab man, standing near to what appears to be his grandson and holding a large picture of his adult son, seemingly missing or dead. The text, then, is bracketed by sorrow and bereavement. It is significant that our final image of the collection is of a family of Arab men, out of focus, looking lost. Bereft of the son/father, the picture reads poignantly as a tableau of loss, an image without explanatory text that starkly reveals the pain of mourning.

Likewise, in her open letter to "Any Would-Be Terrorists," Nye mourns the losses of September 11th; she directly confronts those who would commit such acts and admits to being "furious" and "humble" in her country's pain. Significantly, though, Nye employs the language of family throughout the piece: she claims to feel "closer to you than many Americans could possibly feel" and labels herself their "distant cousin," whose intimacy is manifest in a shared understanding of food. She urges them to not only think of the pain they caused so many in America (including Arab Americans who bear this double burden), but also the detrimental effects that this act has had on American foreign policy in the Middle East. She empathizes with the pain that triggered such action, but again implores any "would be terrorist" to "tell us in words" of their broken hearts. Returning to her familiar call for language, Nye writes, "Read Rumi. Read Arabic poetry. Poetry humanizes us in a way that news, or even religion has a harder time dong. A great Arab scholar, Dr. Salma Jayyusi, said, "'If we read one another, we won't kill one another.' Read American poetry." Paralleling the men's pain with America's, Nye's anger never devolves into a demonization of Arab men. Rather, her plea to read poetry and to understand that Americans do not make their government's foreign policy decisions indicates that killings and other barbarous activity are not isolated to September 11th; rather, as she asserts, "the rest of us will try harder too."15

It is perhaps in this piece where "us," "we" and "they" blur and where Nye identifies at once as an "Arab cousin" and "American 
neighbor"-claiming the landscape of heritage and of birth-that she fully bears witness to her bicultural identity. In short, Nye is both "us" and "them." Rhetorically claiming her Palestinian heritage, she concludes with the line: "make our family proud." Closing thusly, both 19 Varieties of Gazelle and "Letter from Naomi Shihab Nye," with rhetorical and visual markers, return the reader to family, kin and bloodlines. Despite her ability to "pass," Nye's use of corporeal metaphors underscores her material connection to her father and the Middle East. ${ }^{16}$ Nye's body of work, in fact, substitutes for the body, itself; it is a testimonial to her Arab heritage, marking the self through the word.

\section{BEARING WITNESS THROUGH THE NAME}

Incident \#3: Seven weeks ago I gave birth to my son. Being a quarter Iraqi, he will surely pass. When or how he claims his Arab ancestry and whether it will hold the same political weight in years to come is uncertain. As his mother, I struggled with naming. Should I "mark" him as an Arab American? Will language be a gift of heritage or a burden? My son's name carries the map of family, a loving gesture to his Iraqi grandfather whom he will never know, yet it deliberately allows him to pass in his country of birth. ${ }^{17}$ As a friend of mine assured me, choosing a name that goes "both ways" is a survival strategy in a political climate in which Arab Americans are seen by many as the "enemy," fear for their safety, are targeted by governmental authorities, are routinely denied civil rights and are victims of racial profiling and hate crimes. ${ }^{18}$ Yet there is still guilt. I feel guilty for passing on so many occasions knowing my father could not, for wanting my son to have the ability to pass in America and for the recognition that many people of color, including Arab Americans, cannot. Like Nye, this gesture of naming is an attempt to bear witness through the word.

\section{REFERENCES}

Akash, Munir and Khaled Mattawa. "Introduction." Post-Gibran: Anthology of New Arab American Writing. Eds. Munir Akash and Khaled Mattawa. Syracuse: Syracuse University Press, 1999. xi-xiii.

Boudakian, Martha Ani. "Crossing Over to the Other Side." Food 
for Our Grandmothers: Writings by Arab-American and ArabCanadian Feminists. Ed. Joanna Kadi. Boston: South End, 1994. 32-38.

Browder, Laura. Slippery Characters: Ethnic Impersonators and American Identities. Chapel Hill: University of North Carolina Press, 2000.

Derricotte, Toi. The Black Notebooks. New York: W. W. Norton \& Company, 1997.

DuBois, W.E.B. The Souls of Black Folks. 1903. Reprint. New York: Penguin, 1989.

El Said, Maha. "The Face of the Enemy: Arab-American Writing Post-9/11." Studies in the Humanities 30.1-2. (2003): 200216.

Johnson, James Weldon. The Autobiography of an Ex-Colored Man. 1912. Reprint. New York: Penguin, 1990.

Joseph, Suad. "Against the Grain of the Nation-The Arab." Arabs in America: Building a New Future. Ed. Michael W. Suleiman. Philadelphia: Temple University Press, 1999. 257-271.

Halaby, Laila. "Browner Shades of White." Food for Our Grandmothers: Writings by Arab-American and Arab-Canadian Feminists. Ed. Joanna Kadi. Boston: South End, 1994. 204205.

Kadi, Joanna. "Introduction." Food for Our Grandmothers: Writings by Arab-American and Arab-Canadian Feminists. Ed. Joanna Kadi. Boston: South End, 1994. xiii-xx.

Kahf, Mohja. E-mails from Scheherazad. Gainesville: University Press of Florida, 2003.

Majaj, Lisa Suhair. "Arab-Americans and the Meanings of Race." Postcolonial Theory and the United States: Race, Ethnicity and Literature. Jackson: University Press of Mississippi, 2000.

-. "Arab American Literature and the Politics of Memory." Memory and Cultural Politics: New Approaches to Ethnic Literatures. Boston: Northeastern UP, 1996.

Nobles, Anna Y. Sciarra, Daniel T. "Cultural Determinants in the Treatment of Arab Americans: A Primer for Mainstream Therapists." American Journal of Orthopsychiatry. 7.2 (2000): 182-191.

Nye, Naomi Shihab. 19 Varieties of Gazelle. New York: 
HarperCollins, 2002.

--. "Long Overdue." Post-Gibran: Anthology of New Arab American Writing. Eds. Munir Akash and Khaled Mattawa. Syracuse: Syracuse University Press, 1999. 127-132.

-Open Letter to Any Would-Be Terrorist." Islamic Studies . 2002. <http://www.arches.uga.edu/ godlas/shihabnye.html >

Orfalea, Gregory and Sharif Elmusa, eds. Grapeleaves: A Century of Arab American Poetry. Salt Lake City: University of Utah Press, 1988,

Orfalea, Gregory. "Doomed by Our Blood to Care: The Poetry of Naomi Shihab Nye." Paintbrush. Spring (1991): 56-66.

Said, Edward. Orientalism. New York: Vintage, 1978.

Saliba, Therese. "Resisting Invisibility: Arab Americans in Academia and Activism." Arabs in America: Building a New Future. Ed. Michael W. Suleiman. Philadelphia: Temple University Press, 1999. 304-319.

Samhan, Helen Hatab. "Not Quite White: Race Classification and the Arab-American Experience." Arabs in America: Building a New Future. Ed. Michael W.

Suleiman. Philadelphia: Temple University Press, 1999. 209-226. Shakir, Evelyn. "Mother's Milk: Women in Arab-American Autobiography." MELUS 15.4 (1988): 39-50.

Wald, Gayle. Crossing the Line: Racial Passing in Twentieth Century U. S. Literature and Culture. Durham: Duke UP, 2000.

Zoghby, Mary D. "Memory, Image and Identity in Arab American Poetry." Paintbrush Spring (1991): 21-28.

\section{FOOTNOTES}

1 African American literature abounds with passing narratives which, as James Weldon Johnson's The Autobiography of an Ex-Colored Man epitomizes, often position the protagonist as abdicating family and disavowing community for nothing more than " a mess of pottage." A close reading of Johnson's text, though, illustrates that it is the fear of bodily harm-in this case a brutal lynching-that compels the narrator to assume a white identity and move north. The novel, finally, lays blame at the feet of white America for creating a racial climate that induces an African American man to sell "his birthright." Again, racial passing is portrayed not as a necessary act of survival, as the unnamed protagonist's friend Shiny has chosen to devote his life to racial uplift, but as a complicated negotiation of race in the early 20th century.

2 The desire to racialize bodies according to a racist mythology is exemplified in a Georgia hospital where nurses were instructed to discern babies of 
indeterminate race through a "series of procedures posted on the nursery wall. .. among them a procedure to measure the size of its genitals" (Derricotte 182). Despite the medical setting, racial stereotypes prevail and are elevated to scientific truth.

3 Numerous Arab American authors problematize Arabs' white status: "In the United States, we are socialized to believe that Middle Eastern identity is nebulous and liminal, or a European subculture. In actuality the "Middle East" represents a group of ancient West Asian cultures" (Boudakian 36). Likewise, the title of Laila Halaby's poem, "Browner Shades of White" illustrates this dilemma as the speaker states that she feels "erased" by government forms. She further addresses the bifurcation in her own life: "My friend who is black / calls me a woman of color. My mother who is white / says I am Caucasian" (205).

${ }^{4}$ In the nineteenth century, Syria, also known as "greater Syria," encompassed areas of modern day Lebanon and Syria.

${ }^{5}$ Classifying Arabs as "whites" also delegitimizes their racial oppression, which they continue to suffer. Therefore, this is not merely a discursive argument, but has material ramifications. ADC, the America Anti-Discrimination Committee, the largest Arab American civil rights group, urged its members to fill out the U.S. census long form with its question of ancestry in order to begin the arduous process of visibility.

${ }^{6}$ Because Arabs are not a recognizable racial/ethnic group in America, not only do they often go unidentified, other people of color, most notably Indians and Pakistanis, are routinely misidentified as Arabs and often suffer anti-Arab harassment.

${ }^{7}$ When not cast in the role of the submissive house slave, Arab women are constructed as the "scantily-clad and salivated-upon belly dancer" (Shaheen 129). While seemingly antithetical to the oppressed, covered woman, both are objectified and more significantly, provide evidence for Arab men's perceived inherent misogyny.

${ }^{8}$ Joanna Kadi refers to Arabs as "The Most Invisible of the Invisibles" (xix).

9 Toi Derricotte, a light-skinned African American poet, writes of a similar incident of inadvertent passing with a taxi cabdriver, on whom she had come to rely. After several rides, the man, believing his passenger to be white, makes a racist comment. Derricotte's reverie allows for multiple ways of reading this moment-she believes that her racial position provides her with a stronger sense of voice: "We fought all the way to the airport. And it felt good. It was wonderful to be able to fight him without constantly have to get out of the way of the racism in his mind. That's when I realized that it is much easier for white people to confront racism than it is for blacks" (173-174). Derricotte willingly disrupts the simplicity of this seemingly race-free moment, though, as she goes on to reveal that after telling this story at a black college, a woman confronted her: "She said for me to escape the pain while others are not able to made me a betrayer" (174). Here, Derricotte admits that silence "is just as 'wrong'" (174) and she finally tells the cabdriver of her race and ceases riding with him.

10 Likewise, Mohja Kahf's "I Can Scent an Arab Man a Mile Away" presents a 
loving, though not romanticized portrait of Arab masculinity. While they may be "macho, patriarchal, sexist, egotistical, [and] parochial," they are also tender and refined, cushioning the "tumbles of small children" and recognizing "Scripture and poetry." Arab men are also the site of sexual desire in Kahf's poem: "God, they look so sexy in those checkered scarves." The speaker infuses the kafiyya, a garment regarded by the West as a sign of danger, with erotic power, and in so doing deconstructs monolithic notions of Arab masculinity.

${ }^{11}$ Zoghby further contends that, in Arab American poetry, memories of parents are "rivaled only by concerns with oppression and violence in the Middle East" (22), a claim that is true of Nye's work as well.

${ }^{12}$ Language is a chord sounded throughout Nye's collection, yet a poem such as "Lunch in Nablus City Park" vacillates between the import of voice and its inability to capture the materiality of Palestinian lives: "When you lunch in a town / which has recently known war / under a calm slate sky mirroring none of it, / certain words feel impossible in the mouth."

${ }^{13}$ Gregory Orfalea argues that "The Man Who Makes Brooms" is one of Nye's best "protest" poems (58).

${ }^{14}$ In fact, her father's family lost its home and possessions in 1948, when the state of Israel was created.

${ }^{15}$ Unlike Nye, many Arab Americans are fearful of critiquing American foreign policy decision. In many communities or businesses that are decidedly marked as "Middle Eastern," i.e. grocery stores, markets, and restaurants, there were a number of prominent flags, ribbons and other patriotic symbols that appeared in the wake of September $11^{\text {th }}, 2001$ and the subsequent war in Iraq. These overt signs of American patriotism may be read as another form of passing, as some Arab Americans attempted to highlight their American identity and downplay their ethnicity, recognizing the conflation of Arabs and terrorism in the West. While a significant number of Americans vocalized their opposition to the war, many Arabs feared revealing a dissident political position and publicly attempted to "pass" through hyper-patriotic expressions.

${ }^{16}$ It also suggests Nye's affiliation with her brother, whose body signifies ethnicity: he "looks more like an Arab than many full-blooded Arabs do" ("Letter"). Many Arab American writers employ the language of kin: Suheir Hammad writes, "please god. . . don't let it be anyone who looks like my brother" in response to the September 11th attack (qtd. In El Said 202).

17 "Arab Americans from all groups-recent immigrants, assimilated immigrants, or native born-may choose to deny their ethnic background. Abu-Laban and Suleiman pointed out that some Arabs never reveal their ethnic background because of stereotyping. They give as an example the consumer advocate, Ralph Nader, who has seldom (if ever) referred to his Arab lineage" (Nobles and Sciarra 187). Of course Nader's ability to pass is due, in large part, to his Americanized name. Naming, then, is another form of passing. Like other immigrant groups, some Arabs have anglicized their surnames. Indeed, before my father immigrated to the United States, a cousin who had lived in the West advised him to change his surname from Al-Wardi to Wardi. A more recent trend, though, is Arab Americans anglicizing their first names in the public arena 


\section{Ethnic Studies Review Volume 28: 2}

and using their Arabic names only in the home and other safe spaces.

${ }_{18}$ Arab American children, too, recognize the climate of fear. In the days following September 11th, Nye reveals that her brown-skinned nephews have yet to return to school ("Letter"), and Elmaz Abinader in "Profile of an Arab Daughter" writes, "My brother's son asks my sister do you think someone will try to kill my dad?" (qtd. in El Said 205). 